\title{
Scriptural Completion in the Infancy Gospel of James
}

\author{
Markus Bockmuehl, University of Oxford
}

Every authoritative text - perhaps any significant text - involves its hearers and readers in a process of engagement that invites or even requires the filling of gaps or breaks in what is written. ${ }^{1}$

In communities committed to canons of Holy Scripture, this engagement may at times appear to outsiders as little more than rationalization - the exposition of a static document in the service of a concern for authorized meaning. Closer observation, however, tends instead to uncover a complex, historically self-renewing process of relating text to intertext; of nuancing the tensions and suspensions of law and poetry and prophecy differentially; of continually re-reading multiple senses of the text in light of each other; of the interplay of memory, retrieval and aggiornamento within an interpreter's living community of praxis, study and worship.

At the same time, this process sometimes gives rise to a further stage of engagement with authoritative texts, more liminal and yet in other respects more generative than the picture just described. The very genesis of the scriptural texts themselves bears witness to a dynamic process of reception, appreciation and transmission. In so doing the sacred page gives rise to new, epiphenomenal text that may either become an integral part of the emerging scriptural voice or alternatively attain an independent authority of its own as a metatext that nevertheless remains associated in some sense with the generative personality of a Moses or an Ezra, a Paul or a John. This process has long been of interest to students of inter-textual and inner-biblical interpretation, of reception history and effective history, in both the Jewish and Christian scriptures.

While the dynamics of this constellation are to some extent different for the early Christian texts as compared to the Hebrew Bible, their processes of tradition and Fortschreibung suggests distinct lines of analogy that lend themselves to fruitful exploration. Here too the texts that became canonical manifested (as Hindy Najman puts it in relation to Jewish writings) "an excess of vitality that expresses itself in the fact that they provide the basis for new texts", which attempt to "say the same' as the original scripture although they are self-evidently different".2

\footnotetext{
${ }^{1}$ An early version of this article was presented to an international workshop on "Ethical Reading" convened by Prof. Hindy Najman at Oxford in May 2016. I am grateful to her for the invitation and for this opportunity to develop some of my own recent work on the apocryphal gospels (see Bockmuehl 2017). In doing so I have benefited from several of her publications including Najman 2012a, 2012b (and cf. previously Najman 2003, 2010). I also wish to express thanks for comments received from Irene Peirano of Yale University, from members of the Oxford New Testament Seminar, and from the anonymous reviewer for Pro Ecclesia. Parts of this article are developed with permission from my forthcoming book Ancient Apocryphal Gospels, Interpretation: Resources for the use of Scripture in the Church (Louisville: Westminster John Knox, 2017).

${ }^{2}$ Najman 2012b, 512.
} 
The apocryphal gospels furnish a number of interesting case studies of this process in the early Christian context. They typically manifest a notable dependence on gospel texts, sayings or narrative traditions that went on to become canonical. In their literary or (more commonly) oral engagement with those texts these authors take for granted the authority of the proto-canonical narrative outline, but in many cases also of individual sayings or other textual details. At the same time, narrative or topical gaps in the earlier gospel accounts proved highly generative for Christian understandings of Jesus' birth or passion, his encounters with opponents or his teaching discourses after the resurrection. And while it is important to note that most of these texts remained exceedingly marginal and are often attested only in a single manuscript fragment, a small handful went on to exercise considerable influence or even a derivative authority in their own right.

The illustrative case study undertaken in this essay concerns perhaps the single most influential example of that generative dynamic. Stories surrounding the parentage, infancy and childhood of Jesus generated a very large number of ancient and medieval texts in many different manuscript copies and languages. Here I propose to explore the process of scriptural completion in relation to the most famous of these works, the Protevangelium or Infancy Gospel of James. Related texts one could study with benefit include the so-called Infancy Gospel of Thomas, the Arabic Infancy Gospel, the Gospel of Pseudo-Matthew, and the so-called History of Joseph the Carpenter, mostly extant in a variety of textual forms and giving rise in turn to a number of alternative versions or variants. ${ }^{3}$

\section{Explaining Infancy Gospels}

Whether one comes at this literature from the study of the New Testament, of Christian apocrypha or of late antique popular religious writing more generally, the sheer volume, vibrancy and distinctiveness of the infancy gospels calls out for explanation.

While there are undoubtedly numerous factors at work, most pertinent for present purposes is the perceived and perhaps deliberate incompleteness of the four New Testament gospels themselves. To cite only the best known example, the famously sudden and reticent ending of the Gospel of Mark in its most primitive textual form almost immediately (and perhaps intentionally) evoked a series of alternative endings, the most successful of which were those of Matthew, Luke and John - along with Mark 16.9-20 as the form in which that Gospel became canonical, and by which it was already widely known in the second century. ${ }^{4}$

\footnotetext{
${ }^{3}$ See Ehrman and Pleše 201l, Nos. 1-6 (pp. 3-160); cf. Markschies et al. 2012, 1.2:886-1029; 1:308-42.

${ }^{4}$ New Testament scholars are accustomed to claims that the best textual witnesses confirm the "original" conclusion of Mark to have been at 16.8. But while 16.8 does conclude the earliest reconstructable text, this Gospel in fact ends at 16.8 only in a remarkably small number of extant ancient Greek manuscripts, none of which predate the fourth century
} 
Given the New Testament nativity stories' pervasive influence on the history of Christianity, it is easy to forget that only two of its gospels offer us birth and infancy narratives at all. Mark's interest in the background of Jesus extends only to his spiritual home in the ministry of John the Baptist, while the Fourth Gospel finds the origin of Jesus emphatically in his incarnation as the eternal Logos of God. Mark simply drops the adult Jesus into the narrative at the point of his encounter with John the Baptist, but without supplying any account of what precedes (Mark 1.9). John's gospel, by contrast, prefers to delineate his beginnings in philosophical and theological rather than biographical terms and otherwise leaves the reader guessing - even in the face of repeated insinuations on the part of Jesus' enemies about the identity of his father or his place of birth (John $1.46 ; 6.42 ; 7.42 ; 8.19,41)$.

Mark and John thus provide few answers about where Jesus came from, or indeed what he did for the first 30 years of his life. But what accounts for this silence in two of the four New Testament gospels? It has not uncommonly been attributed to their unfamiliarity or rejection of birth and infancy traditions - perhaps including, for John, the Matthean and Lucan claim that Joseph was not the biological father of Jesus.

Absence of evidence is not, however, evidence of absence; and omission cannot by itself confirm ignorance, let alone denial. Mark's Peter and John's Beloved Disciple are staged and remembered by their literary executors in terms of what they saw and heard - by implication placing the narrative camera where it misses out other matters. There may be little reason to suppose that Luke's evident fascination with Davidic family lore or Jesus' human paternity would have played much part in such a considered construal, regardless of whether Mark or John were aware of it. ${ }^{5}$ Yet despite John's stirring and formative identification of Jesus' origin as the divine

(although others were evidently known to Clement, Origen, Eusebius and Jerome). The familiar "longer" (canonical) ending of 16.9-20 apparently dates from the early second century, and is also unattested in pre-300 manuscript fragments of Mark. It appears, however, to be the only conclusion of the Gospel known to several writers from the second century onwards, including Irenaeus and possibly the author of the Epistle of the Apostles as well as Justin Martyr. One other Marcan ending in the late 4th-century Codex W deploys the so-called Freer Logion, expanding a Marcan text to which 16.9-20 is already integral (cf. Frey 2012, 1060).

The composition of 16.9-20 draws extensively on motifs known in all three of the other proto-canonical gospels, but also features prophecy about apostolic miracles found in the Book of Acts as well as in one tradition about apostolic immunity from poison (cf. further Black 2008; Kelhoffer 2000; also Heckel 1999, 281-86). Mark's canonical ending instantiates a remarkably successful scriptural completion or Fortschreibung of the sort here under discussion in relation to the Infancy traditions. What is more, as with the Lucan infancy narrative it is worth asking if the original Marcan composition may have implicitly solicited the supplementation it almost immediately received in Matthew, Luke and its own endings (the canonical 16.9-20 as well as its apparent derivatives, the shorter ending and the Freer logion).

${ }^{5}$ The Fourth Evangelist has sometimes been seen as ironically implying precisely that: an awareness of certain traditions while lacking either interest or authority (John 7.42; 8.19, 41; and cf. in that light 1.46; 6.42). It has likewise been thought that while Paul appears to acknowledge Peter's seniority as a source and authenticator of tradition (Gal 1.18), he claims

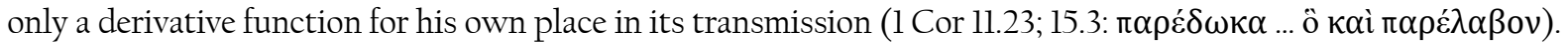


Word made flesh, evidently no one looked to either John or Mark for encouragement to think more deeply about Jesus' childhood, birth and family background. For Mark and John, then, 'high' Christology appears not to require a miraculous nativity. ${ }^{6}$

Matthew and especially Luke by contrast implicitly invite the thought that there may have been rather more of interest in Jesus' birth and origin than is recorded in their relatively economical narratives, let alone in the even more taciturn Mark and John. One still finds here little interest in the biography of Joseph or of Mary the mother of Jesus, or indeed much focus on his childhood or youth until he emerges from the shadows in his late 20s as a follower of John the Baptist.

Particularly in view of the ground they concede to narrative interest in the birth of Jesus, both Matthew and Luke seem to invite further elaboration about his family origins and infancy almost by design. Matthew, for example, tantalizingly abandons his economical narrative of the boy Jesus not long after his return from Egypt perhaps not yet three years old, resuming only with the 30-yearold's baptism by John (cf. Matt 2.16; 3.13).

Luke never asserts, nor ever attracted, a close literary association with the name of an apostle. He does, however, claim to have consulted eyewitnesses - and that the contemporary who thought more about the nativity than anyone else was Jesus' mother Mary. It is Luke who introduces the motif that Mary's story matters even before Jesus is born, and that implicitly it matters more than Joseph's. For Luke it is Mary who synthesises the theological significance of the Annunciation and birth of Jesus - perhaps above all in the Magnificat (Luke 1.46-55). The Lucan stories of the Nativity and of the boy Jesus in the Temple at Passover are each followed by the assurance that 'Mary treasured all these words and pondered them in her heart' $(2.19,51)$. And these two stories bracket a childhood of Jesus about which the evangelist tells us not once but twice that 'the child grew and became strong, filled with wisdom; and the favour of God was upon him' (2.40; cf. 2.52). In this way he unabashedly implies that there was a great deal more to think about than he records.

So there can be little surprise in the discovery that Christian piety and imagination should find in these texts an incentive to ask and imagine what else might have been the subject of Mary's reflection during this period surrounding the birth and infancy of Jesus. Early Christian writings testify to a widespread and continuing interest, not least among Jewish Christians, in the human origins of Jesus as well as in his relatives and their descendants. They were known as the desposunoi, "the Master's people", i.e. the Lord's human relatives. ${ }^{7}$ Examples include the second-century traditions about the grandsons of Jesus's brother or half-brother, Jude, as documented by the

\footnotetext{
${ }^{6}$ Cf. the discussion in Frey 2011.

${ }^{7}$ So e.g. Eusebius, Eccl. Hist. 1.7.14; cf. 3.11, 20, 32.6. See the discussion in Bauckham 1990; Lambers-Petry 2003.
} 
second-century writer Hegesippus. ${ }^{8}$ Assertions about his virginal conception and Davidic descent also attracted extensive interest and debate on the part of Christians themselves and, more sceptically, of their enemies. ${ }^{9}$

It is similarly significant, perhaps, that both Matthew and Luke articulate a public dimension for these otherwise sketchy childhood stories: we read about magi, shepherds, a presentation in the Temple, correlations to 'public' historical events or figures, and so on. And for both gospels these events are profoundly relevant to the identity of Jesus as the scripturally adumbrated Messiah who emerges fully in the later narrative.

This background goes a long way towards accounting for the attraction of gospel-like stories elaborating the family, birth and childhood of Jesus. Devout imagination found plenty of food for curiosity in the evocative but only minimally sketched infancy narratives of Matthew and Luke.

It is important to bear in mind that such stimulus to textual development was not just light entertainment. Early Christians clearly recognized in the infancy stories an invitation to prolific devotional and theological engagement with the nature of the incarnation - and thus with some of the most basic challenges of Christology. How human was this man? How divine? And in what sense could he be fully the Son of David, yet also born of a Virgin and the eternal Son of God? We turn to the Infancy Gospel of James for one set of answers to these questions.

\section{The Infancy Gospel of James}

The Infancy Gospel or Protevangelium ('Proto-Gospel') of James is as such largely unknown to most Protestant and Catholic readers - even if, as we shall see, its influence is in fact far more extensive than many realize. It has received very little media attention in recent discussion compared with the gospels in the names of Thomas, Judas or Philip. Dan Brown's The Da Vinci Code leaves books like this well alone, and even conservative apologists like Bock 2006 and Jenkins 2001 find little need to discuss it. ${ }^{10}$

In fact, however, it is this work which astonishingly towers above all other apocryphal gospels in its effect and influence on subsequent Christian tradition and piety. Quite unlike any other non-canonical work, this infancy gospel has profoundly shaped how most Christians through the ages and into the twenty-first century have understood and imagined the Christmas story regardless of whether they have ever even heard of this text.

\footnotetext{
${ }^{8}$ Hegesippus in Eusebius, Eccl. Hist. 3.19-20.

${ }^{9}$ For a fuller discussion of traditions surrounding Jesus' Jewish and Davidic descent see e.g. Bockmuehl 2011.

${ }^{10}$ Text and English translation are readily accessible in Ehrman and Pleše 201l; Ehrman and Pleše 2014.
} 
This Infancy Gospel concerns the events leading up to the birth of Jesus and immediately following it. It extends the New Testament narratives significantly and makes Mary the mother of Jesus its central character, notably beginning with episodes about her own family background, birth and childhood. Its designation Protevangelium reflects its concern for what might be called 'the gospel before the gospel'. We begin with a brief survey of its content, origin and textual attestation before offering some suggestions about its place in relation to the early Christian scriptural traditioning process. ${ }^{11}$

\section{The Story}

The first seven chapters of the work deal with the conception, birth and childhood not of Jesus but of Mary, the daughter of devout and well-to-do Jews by the name of Anna and Joachim, who until that time had been childless. In reflecting on his childlessness, the Infancy Gospel's Joachim is confronted with a belief that childless Israelites are accursed (which also surfaces repeatedly in Origen, Jerome, Augustine and other church fathers on the basis of a popular but questionable generalization from certain Old Testament passages like Lev. 20.20-21; Jer. 22.30). Joachim seeks anxiously to probe the reasons for his exclusion, fasting for forty days and nights in the wilderness. Anna similarly expresses bitter lament about her condition.

After two visions of angels announcing Mary's birth, Anna in her joy vows to offer the child to the service of God. Great rejoicing follows the birth of Mary, who grows precociously and walks at just six months. From the age of three, Mary grows up in the Temple - a motif strikingly similar to Anna's Old Testament namesake Hannah, whose divinely given child Samuel is also given back to God's service in the Israelite shrine at Shiloh (1 Sam 1).

In chapters 8-16, Mary reaches adolescence and is engaged to her guardian Joseph, a widower with several children from a previous marriage. In Joseph's absence Mary joins a team of virgins weaving a curtain for the Temple. During this time the angel Gabriel visits her at a well and announces the birth of Jesus - despite its fuller narrative detail, this episode shows particular similarities with the Lucan infancy narrative (1.26-38; cf. Matt 1.21).

As in Luke, Mary soon goes to visit her relative Elizabeth for three months; Elizabeth's husband Zechariah is here presented as the High Priest. Joseph's return to find Mary pregnant brings considerable consternation despite Mary's protestations of innocence. Here the narrative introduces and expands a number of motifs from Matthew's narrative. Joseph agrees to shelter and

\footnotetext{
${ }^{11}$ While this notion is relatively widespread, the terminology of an ongoing generative "traditioning process" is associated particularly with the Old Testament scholarship of Walter Brueggemann (see e.g. classically Brueggemann 2003, 8-12). It is, even with some critical reservations, useful in understanding early Christian dynamics as well.
} 
protect Mary after an angel visits him in a dream. Jewish priestly authorities take a keenly probing and critical interest in the irregular pregnancy.

Chapters 17-24, finally, present the story of the birth of Jesus, following the synoptic narrative. Thus Joseph and Mary travel to Bethlehem (though it is not clear if they are coming from Galilee). Mary rides on a donkey that is led by Joseph's older son, perhaps the James who is identified as the older brother of Jesus and the author of this document. Mary gives birth to Jesus in a cave while Joseph is out looking frantically for a midwife. At this point, chapter 18 , he relates a vision in which suddenly the whole of time stands still - with clouds and birds paused in mid-air, animals and people in frozen suspense as the Saviour is born. ${ }^{12}$

The baby Jesus is born in Joseph's absence and in chapters 19-20 Mary's virginity even after the birth is verified by a recklessly nosy midwife Salome whose hand is burned in the process and then healed by the baby Jesus. The focus then turns to the familiar narrative of the magi and the Holy Family's flight to Egypt to escape Herod's massacre of the children, which here threatens even John the Baptist and results in the murder of his father Zechariah by Herod's soldiers (ch. 23). The text ends with the appointment of a new high priest named Simeon and the concluding statement from the author about the circumstances of the document's composition by James in Jerusalem during upheavals following the death of 'Herod', i.e. presumably either Herod the Great in 4 BC or perhaps more likely Herod Agrippa I in AD 44, whose brief reign had included a severe persecution of Christians (see Acts 12.1-23).

The work has been designated by different titles throughout history, although the earliest manuscript (Codex Bodmer V of the third or fourth century) identifies it as 'Birth of Mary Revelation of James'. ${ }^{13}$

\section{Origin and Setting}

Scholarship on this work has long since recognized the text's dependence on numerous details in the final form of both Matthew and Luke - or at least on redactional elements of both their narratives. In dealing with non-canonical gospels it is often impossible to prove any literary dependence on the canonical gospels or indeed whether such dependence may somehow reflect these two New Testament gospels in aggregate, perhaps via an informal oral harmony. Notions of 'secondary orality'

\footnotetext{
${ }^{12}$ This highly influential motif in subsequent Christian reflection on the birth of Jesus also had many parallels in other ancient religious contexts: see e.g. Bovon 1991, 399; Pellegrini 2012, 924 n.139.

${ }^{13}$ Cf. Ehrman and Pleše 2011, 32.
} 
or 're-oralization' have long been familiar in studies of the gospels, and are particularly relevant here. $^{14}$

For purposes of dating, a first and perhaps obvious point of reference is that this fact of dependence on the synoptic tradition establishes the implied link with the figure of James to be fictional. This 'James' is evidently James the Just, the brother of Jesus, who was martyred in AD 62, potentially two or three decades before the composition of Matthew and Luke. The document's composition is therefore unlikely to predate the second century.

In fact, however, the Infancy Gospel makes remarkably little of its supposed connection with James the brother of Jesus: he appears only in the first-person postscript of chapter 25 and in the two-part title at the end. (That colophon's reference to the "Revelation of James" sits awkwardly with "Birth of Mary" and does not seem to relate easily to the document's content.) In the Greek, James is identified by the Hebraizing form of the Old Testament name 'Jacob' ('I $\alpha \kappa \omega ́ \beta$, cf. יעקב) rather than in the Hellenized New Testament form 'Ió $\kappa \omega \beta$ os, traditionally translated 'James'. Only in Chapter 18 does any speaker or narrator assume a first-person voice - and then that person is not James but Joseph. From this perspective it is significantly only the reception history of this document that firmly identifies the speaker of chapter 25 with the brother of Jesus.

Such a secondary attribution is of course not dramatically different from the named authorial associations of the canonical gospels. Most scholars agree that the title does indeed intend an attribution to the brother of Jesus. He is known (from the New Testament, from the Jewish historian Flavius Josephus and from second-century Christian authors like Hegesippus) to have been held in great affection as the respected leader of the Jesus movement in Jerusalem and Judea during the 40s and 50s of the first century. Several other surviving documents from diverse points on the early Christian spectrum are associated with his name, including the New Testament epistle of James and several sources incorporated in the late second or early third-century pseudo-Clementine and Nag Hammadi collections (the Epistle of James to Peter, the Apocryphon of James and the Second Apocalypse of James). So the Infancy Gospel certainly follows a familiar path in appealing to this important apostle. More specifically, we may speculate that for our author and his community the attribution to this particular personality might even have carried a certain biographical plausibility in relation to this Nativity setting: unlike most other figures of the apostolic generation, James could be envisaged as having had uniquely personal access to the childhood of Jesus.

\footnotetext{
${ }^{14}$ See classically Ong 1982, 136 and passim; cf. especially Byrskog 2000, 138-44 on the canonical gospels and e.g. Kirk 2007 on the Gospel of Peter.
} 
The time and place of composition remain widely and inconclusively disputed. The author seems at one level notably sympathetic to Palestinian Jewish piety, although only superficially and inaccurately acquainted with its particularities of belief and practice, or for that matter even its geographic setting. There are, for example, some peculiar ideas about Jewish ritual and legal praxis, and the author seems a little unclear about whether Bethlehem is in Judaea or outside it. Vaguely Palestinian sensitivities combine with an unsophisticated Septuagintalizing Greek to produce a perspective that shows some cultural proximity to the milieu of Matthew, the Didache and the Lucan infancy stories.

As is the case in these other writings, Christianity's Jewish origins are evidently of considerable theological importance for our author - and this point is sometimes overlooked by attempts to classify our text as a popular Graeco-Roman novel or perhaps a historicizing encomium, i.e. an accolade or florid expression of praise. ${ }^{15}$ The Protevangelium, whether of Syrian or perhaps Egyptian origin, relates to Christianity's Palestinian Jewish origins with distinctly greater vested interest and sympathy than is the case for most Christian literature of its time, i.e. between the late first and the early third century. (A broadly second-century date seems required by dependence on Luke and Matthew on the one hand and the citation in Origen on the other; the earliest manuscript evidence appears c.300.)

The Infancy Gospel of James is moreover repeatedly quite moving and enthusiastic in its affection for the Holy Family. At the same time, its hagiography rarely if ever comes across as crassly exaggerated or apologetic (except perhaps in its stress on the miraculous circumstances of the birth, 18-19).

Any apologetic notes remain at a relatively simple and popular level. For this reason, they cannot be seen as any kind of concerted late second-century response to the attack on Christianity's origins by the second-century pagan scholar Celsus (fl. c.170-180?), as is sometimes claimed. ${ }^{16}$ In fact it seems just as plausible that Celsus's learned and well-informed attack was itself prompted in part by a distaste for florid popular Christian hagiographies, including views about Jesus' infancy. ${ }^{17}$ The Infancy Gospel of James may instead anticipate or forestall the sorts of allegations about the origins of Jesus and Mary that Celsus picks up from his Jewish source. The level of engagement or response is certainly too popular and unspecific to suggest any explicit awareness of Celsus.

\footnotetext{
${ }^{15}$ For examples see Hock 1995, 10, 15-20.

${ }^{16}$ So e.g. Ehrman and Pleše 2014, 21.

${ }^{17}$ Cf. Origen, Against Celsus 1.28, 32.
} 
The question of composition is complex but not particularly enlightening for our purposes. Nineteenth-century scholars proposed a number of sophisticated source and composition theories. But in the absence of textual evidence, confidence about elaborate literary hypotheses is today less common. Although many would still allow for the possibility of multiple sources, the general consistency of style and vocabulary probably does at least favour a single editorial hand in overall charge (so already de Strycker 1961).

Readers sometimes wonder if there can be any kernel of historical reference here. Most scholars regard this infancy gospel as historically worthless, except as a source of second-century piety; and that does seem the safest point of departure. Our text may be assumed to document primarily the second century rather than the first. It illustrates how the family background of Jesus and of his mother were understood in second-century Christian circles sympathetic to Jewish faith and practice.

A standard critical objection to the notion of any early tradition here is that the document's knowledge of first-century Judaism appears romantic and clichéd as well as full of wildly implausible factual errors about the realities of Jewish daily and religious life. In particular, Mary growing up in the Temple, the priestly authorities strangely requiring Joseph to undergo the ordeal of drinking 'water of refutation' (cf. Num 5.11-28 for the woman suspected of adultery), the influential notion of Mary's continuing virginity even after the birth of Jesus, and Zechariah the father of John the Baptist being murdered by Herod the Great have all seemed legendary, implausible and fanciful.

This judgment is certainly a useful default position. In my view one should nevertheless allow for the possibility that while the writer has no independent access to earlier sources, he seems occasionally to be drawing on traditions that were already a popular and indeed largely unquestioned part of the tradition of gospel reception by the early second century. In one or two cases these traditions might conceivably have been nourished by a living memory of the apostolic generation. Among these are ideas like the birth of Jesus in a cave, which patristic writers from the Palestinian-born Justin to the Bethlehem-based Jerome both accept. Another pertinent motif is the insistence that Mary too is connected to the Davidic line, a belief widely attested from the second century onward and eventually linked to a particular exegesis of Luke. ${ }^{18}$

More tentatively, attention has also been drawn in recent study of this text to the extraordinary claim noted earlier - that the young Mary, like Samuel at Shiloh, grew up in and around the Temple precinct. It is possible that in this instance, as in one or two others, the vitality of

${ }^{18}$ Luke 1.27; see further Bockmuehl 2011. 
free-ranging legend is interwoven with a slightly better understanding of first-century circumstances than is sometimes allowed for. An interesting case in point is the priestly decision in chapter 10 to assign Mary to a team of young virgins employed in spinning precious thread used to manufacture a new curtain for the Temple. This has struck many a modern interpreter as charming and far-fetched in equal measure. But it transpires that Jewish sources repeatedly acknowledge the existence of teams of young girls continually involved in weaving replacements for the numerous curtains in the Temple (including, but not limited to, the parochet, the main curtain separating the Ark and the Holy of Holies from the main hall of the Temple, veiling it from sight). Evidence for this is suggested in a late first-century text like 2 Baruch 10.18-19 and confirmed in early rabbinic literature. ${ }^{19}$ Some later patristic reflection saw in Mary's weaving the curtain an allusion to the heavenly Temple's curtain as Christ's flesh (Hebrews 10.20) being 'woven' in her womb. ${ }^{20}$

One insightful recent treatment notes the intriguing correlation between Mary's threefold role as (1) consecrated to the service of God, (2) accused of sexual immorality and (3) a virgin involved in producing the Temple curtains. This triad of identities corresponds to the only three groups of women who filled an official function in the Temple: female Nazirites, accused adulteresses seeking vindication, and virgins who made the Temple curtains. By connecting all three motifs to the Temple, the writer managed to offer Christians a narrative of origins that remains rooted in Israel's Scripture while also answering Jewish attacks on Mary. ${ }^{21}$ This does not of course establish anything at all about 'historicity', but it does perhaps suggest a religious and hermeneutical setting of this proto-gospel's narrative dynamic that stands in closer awareness of Palestinian Jewish realities than has often been acknowledged.

\section{Interpretation}

As we have seen, despite its title this turns out to have nothing to do with James and very little even with the birth and infancy of Jesus. It is instead clearly concerned with Mary first and foremost, and only then with the incarnation and birth of her son - although of course for this author the importance of the former is clearly a function of the latter. As a result, the alternative designation Protevangelium is highly appropriate. This work tells the story of Mary; it is thus indeed a gospel before the gospel, articulating a religious context for the Matthean and Lucan gospel nativity.

\footnotetext{
${ }^{19}$ See e.g. Tosefta Sheqalim 2.6 and possibly as early as Mishnah Sheqalim 8.5; cf. Babylonian Talmud Hullin 90b; Tamid 29b. Note also the discussion in Ilan 1997, 139-43.

${ }^{20}$ Constas 2003, 330 in a discussion (pp 325-31; esp. 325 n.21) of the Protevangelium's influence on the fifth-century writer St Proclus of Constantinople: "When Mary devotedly spins the wool for the veil of the temple, the labor of her hands serves as a symbol for the labor of her womb."

${ }^{21}$ See Nutzman 2013, 553-54, 578 and passim.
} 
The unfolding of this story entails a great deal of implicit Christology. Aside from the emphasis on Mary's virginity, along with her Davidic and Temple connections, perhaps the most poignant confirmation of this is the moment of the incarnation itself, when in Joseph's vision time stands still and creation pauses in worshipful astonishment at the divine birth. To be sure, in antiquity the broader motif of signs and wonders at an important birth had many parallels in other contexts, ${ }^{22}$ as for example miraculous signs and favourable dreams and omens were also narrated in connection with the poet Vergil's birth. ${ }^{23}$ At the same time, Christian reflection on the nativity continued throughout the centuries to be captivated by Joseph's vision. Among the more striking twentieth-century interpretations is Norman Nicholson's 1951 poem “A Turn for the Better," which takes its opening line from the paradoxical statement in 18:2, "I, Joseph, was walking, and I walked not."

It is certainly possible that the birth narrative's implicit Christological theme carries twin apologetic implications, in safeguarding on the one hand the authentically Jewish birth of Jesus from the line of David, while on the other hand ruling out a purely human, adoptionist Christology of the sort that was apparently current in some more sectarian Jewish-Christian circles. The primary and explicit focus is at any rate very much on Jesus' birth as the gift of a pure, obedient and miraculously graced mother.

The Infancy Gospel is an early example of Marian theology in the service of Christology. This Marian emphasis in fact is explicitly foregrounded by the document's ancient title as given in chapter 25.4: "Birth of Mary - Revelation of James". One important overarching aspect of this appreciation of Mary is that of her purity (words like $\kappa \alpha \theta \alpha \rho$ ó and $\alpha \mu i \alpha v \tau o s$ are frequent), developed with a threefold emphasis on Temple purity, menstrual purity and sexual purity. ${ }^{24}$ The narrative reiterates this theme from the story of Joachim and Anna to Mary's birth, childhood and virginal motherhood of Jesus.

Another reason the Marian connection is so important is because this text explicitly affirms that Mary too is of the 'tribe' of David, as we saw (10.1). This intriguing and highly charged conviction is never mentioned in the New Testament, but came to be of key importance for Jewish Christians and others concerned to stress Jesus' true status as Messiah of Israel - grounded in his biological descent from David, as the prophets had envisaged.

\footnotetext{
22 See Bovon 1991, 399; Pellegrini 2012, 924n139.

${ }^{23}$ Suetonius, Vergil 3-5.

${ }^{24}$ See further Vuong 2013.
} 
The New Testament gospels notoriously fail to resolve a problem at the heart of their genealogies of Jesus: they focus on the Davidic descent of Joseph, a man who was for all of them emphatically not the father of Jesus. Modern critical commentators tend to assume this problem is solved by Joseph's adoption of Jesus as his son. But in ancient Judaism it was not possible to acquire a valid genealogy by adoption ${ }^{25}$ - a point not lost on Christianity's second-century Jewish critics, who sometimes liked to assert that Jesus' doubtful paternity concealed his true origin as the bastard son of a Roman soldier. (These were among the polemical accusations picked up by the accomplished pagan critic Celsus in his anti-Christian treatise The True Discourse. ${ }^{26}$ )

The Infancy Gospel of James thus sets a highly influential precedent for the history of Christian doctrine when it draws so heavily on Mariology in support of its Christology - even when it comes to Christ's human descent from David. Here we do well to remember the prominence of Mary in the fifth-century Nestorian Christological controversy about Mary as "mother of God" (theotokos). But this recognition of the importance of Mariology to Christology is in fact not without parallel even in the second century. Another early writer to hint at this is Ignatius in his letter to the Ephesians (19.1; cf. 8.2 'son of Mary and Son of God'), and Luke's gospel of course implicitly identifies Mary as instrumental through the narrative of the Annunciation and the Magnificat (Luke 1.31-35, 48-49). But the Infancy Gospel does seem to be the first text to give explicit narrative articulation to her unique role. On this as on one or two other fronts, it seems at least conceivable that our text incorporates pre-existing Christian traditions - even if this is admittedly difficult to prove in any given case.

\section{Transmission and Influence}

One of the effects of the Infancy Gospel is to accentuate even further the concern in Matthew and Luke to tether the gospel of the incarnation to an account of the origins and infancy of Jesus. Although our text is only about $25 \%$ of the length of Matthew, that still of course enormously inflates the sheer bulk of the infancy traditions (which constitute less than 5\% of Matthew).

More telling for this text's outstanding prominence and influence among comparable early Christian Apocrypha, the Infancy Gospel generated a far larger manuscript tradition than any other non-canonical gospel. The standard critical edition of Émile de Strycker 1961 (cf. de Strycker 1980)

\footnotetext{
${ }^{25}$ This is rightly stressed by Levin 2006, although his inference of the tradition's Gentile origin does not follow.

${ }^{26}$ Cited in Origen, Against Celsus, 1.28, 32.
} 
was able to draw on over 140 mostly mediaeval Greek manuscripts, of which the earliest dates back to the third century; today the inventory extends to over 150 manuscripts. ${ }^{27}$

The Greek textual tradition also generated translations into at least eight other ancient languages including Armenian ${ }^{28}$ and especially Arabic, which in turn may have had some influence on the considerable prominence of Mary in the Qur'an and traditions of the hadith. Scholarship has increasingly noted the possible influence of pre-Islamic Jewish Christianity in the Arabian Peninsula. ${ }^{29}$ In this respect it is interesting to recall the widely cited tradition of Mohammed protecting the icon of Mary and Jesus when the Kaaba in Mecca was purged of idolatrous images (according to the ninth-century Meccan writer Al-Azraqi's book Akhbar Makka ${ }^{30}$ ).

No early Latin translation of the Infancy Gospel of James survives. Its relative eclipse in the Western Church is due partly to its rejection in documents beginning possibly as early as the Letter to Exsuperius by the early fifth-century Pope Innocent $\mathrm{I}^{31}$ and explicitly around the end of that century in the so-called Gelasian Decree. ${ }^{32}$ More influentially, perhaps, it was displaced by becoming extensively re-used by other infancy gospels in Latin. In this way, before long it re-entered the Western tradition by spawning several secondary apocrypha. ${ }^{33}$ Of these, Pseudo-Matthew alone accounts for over 200 extant manuscripts. ${ }^{34}$ Other important derivatives include the so-called Arundel recension of Pseudo-Matthew ('Latin Infancy Gospels') and the History of Joseph the Carpenter. Several Marian narrative themes from the Infancy Gospel are widely acknowledged to have exercised a profound influence on the development of Christian art through the ages. ${ }^{35}$

\section{Christmas and the Infancy Gospel of James}

To illustrate the Infancy Gospel's authority and influence, it may be helpful to consider some of the ways in which this narrative can be seen to have irreversibly influenced basic aspects of Christianity's celebration of Christmas. My suggestion here is in fact that the Infancy Gospel's pervasive effect on the Christian imagination has made it difficult to envisage the Christmas story without certain distinctive aspects of its articulation in this extra-canonical - but evidently metacanonical - tradition.

${ }^{27}$ Cf. Pellegrini 2012, 910.

${ }^{28}$ Cf. Terian 2008.

${ }^{29}$ See e.g. Gnilka 2007.

30 أخبـار مكـة وما جـاء فيـهـا من الآثـار: see ed. Wüstenfeld 1861, 105.

${ }^{31}$ Para. 7; cited somewhat too confidently in Ehrman and Pleše 2011, 32.

${ }^{32}$ Key studies include von Dobschütz 1912; also Chapman 1913; Grossi 2001; Schwartz 1930.

${ }^{33} \mathrm{Cf}$. Voicu 2011, 406-08 on this intriguing phenomenon.

${ }^{34}$ For this and related texts see e.g. Ehrman and Pleše 2011, 73-155.

${ }^{35}$ See Jensen 2015. 
Ten points may here be singled out, presented roughly in the order in which they appear in the text. Some of these may well be familiar to most readers, while others are a staple only in certain Christian traditions.

1. The overall frame of the work takes for granted that Mary's parents were a devout Jewish couple called Joachim and Anna. This is a theme important to Catholic piety through the ages: both Catholics and Anglicans, for example, commemorate the feast day of Saints Joachim and Anna on July 26; the Orthodox church, on September 9. Further in relation to the interest in Mary's parentage, we may mention prominent Catholic and Orthodox feasts like those of Mary's Immaculate Conception on December 8 (December 9 for the Orthodox), her birth on September 8 , and her presentation in the Temple on November 21. In the West, by the early fourteenth century it seemed wholly unproblematic for Giotto's (1266-1337) famous frescoes in the Scrovegni Chapel at Padua to include several scenes from the lives of Joachim and Anna.

2. We have already noted the affirmation in 10.1 that Mary was of the 'tribe' of David. It is this (and only this) conviction that provided a genealogically credible explanation of the infancy narratives' identification of Jesus as descended from David.

3. A theme less familiar to Protestants is that the Annunciation occurred while Mary was fetching water, perhaps from a well (11.1-2). Whether (as here) in Jerusalem or in Nazareth, a well associated with the Annunciation has long featured in icons and narrative accounts - possibly already in an early third-century fresco at the Christian baptistery of Dura Europos in Syria. ${ }^{36}$ Such a site has been pointed out to pilgrims through the ages, and still to this day, at the Orthodox church of the Annunciation in Nazareth.

4. At 17.2 Mary rides a donkey to Bethlehem. This especially is a theme without which Christmas pageants or even Hollywood movie representations like The Nativity Story (2006) are unthinkable. Adults and children alike tend to take this as integral to the biblical Christmas story. A motif more surprising to Western Christians is that in the Infancy Gospel the donkey is driven along by James (one of several older sons of Joseph from a previous marriage, 18.1). Coptic and Eastern Orthodox icons often feature James as well as Joseph in scenes like the Holy Family's flight to Egypt.

5. Notably, at 18.1 we are told that Jesus was born in a cave. As we saw earlier, this tradition was accepted by Justin Martyr in the second century and Origen in the third, while the associated

\footnotetext{
${ }^{36}$ This possibility is noted in an important study by Peppard 2012, 545-56.
} 
site was regarded as historical and unambiguously identifiable by Jerome in the fourth ${ }^{37}$ It is a standard feature of orthodox iconography. By contrast, the popular notion that there was no room in the 'inn' at Bethlehem derives from a common misreading of Luke 2.7 (KJV), where the Greek word $\kappa \alpha \tau \alpha \dot{\lambda} \lambda u \mu \alpha$ probably means the guest room of a house - perhaps in this case the vestibule of a cave dwelling. The replacement of the cave by a wooden stable structure is a feature of late Western art. (Interestingly, Duccio di Buoninsegna's Nativity with the Prophets Isaiah and Ezekiel (1308-11) combines Byzantine with newer Western motifs in placing a wooden stable inside a cave.) The Infancy Gospel makes little of the notion that the infant Jesus was laid in a manger - seeing here mainly a device to help Mary hide Jesus from the persecution of Herod (22.2). Unlike most artistic representations it also does not mention the presence of an ox and an ass.

6. Strikingly, Joseph is absent at the birth because he has gone out to find a midwife. This is a perspective also retained in the standard Orthodox icon of the Nativity (18.1).

7. Not just one but apparently two midwives are eventually located $(19.1,3)$, one of them called Salome. Although they arrive too late to witness the birth, they do assist in its aftermath. In the Nativity icon the two midwives are often seen washing the baby as a way of illustrating the physicality of the incarnation.

8. It is perhaps also worth noting the theme of a bright light appearing inside the cave (19.2). This was a familiar staple of innumerable paintings of the adoration of the shepherds or the magi, including in Western Art: the light illuminating the faces of the shepherds and wise men typically emanates from the baby Jesus himself.

9. In an affirmation of considerable consequence for subsequent Christian doctrinal reflection, Mary is said to have remained a virgin even after the birth - a fact verified to alarming effect by the midwife Salome (16.1-8; 19.8; 19.19-20.12). ${ }^{38}$ The concept of perpetual virginity has a partial Jewish antecedent in Philo's description of Sarah ${ }^{39}$ and may possibly have Jewish-Christian associations (so Horner 2004). It became Christologically important for John Chrysostom, the Cappadocian Fathers and Augustine, and may be implied in the creeds; it was explicitly affirmed at the sixth ecumenical council (Constantinople, AD 681) and remained normative even for

\footnotetext{
37 Justin, Dialogue 78; Origen, Against Celsus 1.51; Jerome, e.g. Letter 46.11; 58.3; 108.10.

${ }^{38}$ It is conceivable, as Pro Ecclesia's anonymous reviewer suggests to me, that the burning of Salome's hand evokes the analogy with God striking Uzzah for touching the Ark of the covenant (2 Sam 6.6-7). The patristic typology of Mary as the Ark is not, however, found in the Protevangelium and may not predate the fifth century by much, although the motif of Christ's body as the Ark is attested in Hippolytus (c. 170-236): Comm. Dan. 4.24.3, 5; Fr. Ps. 19.1 (on Ps 23). ${ }^{39}$ See e.g. Prelim. Studies 7; Posterity 134 and further discussion in Sly 1990; Warner 2003.
} 
Martin Luther. ${ }^{40}$ As we saw, the Infancy Gospel thus already supports the ancient tradition that the brothers and sisters of Jesus mentioned in the gospels are half-siblings: Joseph is explicitly said to be an older man with sons from a previous marriage (9.2 and passim)..$^{41}$

10. Finally, the Infancy Gospel also affirms that the star of Bethlehem was explicitly the brightest in the sky and dimmed all other stars (21.2). This is nowhere stated in Matthew's gospel but came to be assumed by iconographers of the Nativity. Although perhaps an understandable extrapolation from the Matthean text, it clearly received explicit support from the Infancy Gospel.

Many of these points are usefully illustrated by reference to the history of Eastern and Western Christian art. $^{42}$

In its devout development of early Christian beliefs about Mary and the birth of Jesus, the Infancy Gospel of James shaped mainstream Christian piety in both East and West. While it always remained extra-canonical, the Infancy Gospel rarely, if ever, became 'apocryphal' in any sense - either of secrecy or of heresy. Its popularity well outside scribal circles is also documented in the important fact that in the Eastern churches it went on, like other Marian apocrypha, to be read liturgically at various distinctive feasts of the Virgin. ${ }^{43}$ This influence continues today at the Orthodox Feasts of the Nativity of Mary or of her Entrance into the Temple.

All in all, this Infancy Gospel's impact on later Christian theology, spirituality and artistic expression was enormous - more than one interpreter has said that its importance therefore "cannot be overestimated'. ${ }^{44}$ Its manuscript tradition and circulation is out of all proportion to other noncanonical gospel texts. Indeed one may say without exaggeration that the Infancy Gospel of James along with its later derivatives is the only ancient non-canonical gospel text to have enjoyed such a wide and lasting influence (even if the public reading of the Diatessaron in the Syrian churches made it for several centuries an important quasi-canonical exception to this rule). Other, lately famous and controversial gospel texts in the popular limelight are, by contrast, known from at best a handful of manuscripts - more often just a single one.

\footnotetext{
${ }^{40}$ See e.g. Luther 1883-2009 (Weimar Edition), 6:510; 11.319-20; Luther 1955-86 (American Edition), 22.23; 45.206; Table Talk No. 4435.

${ }^{41}$ Bauckham 1994 is among those who have argued that it could be historically factual. This tradition of half-brothers is also affirmed in the Infancy Gospel of Thomas 16.1-2 and by Origen (Commentary on Matthew 10.17, apparently confusing the Gospel of Peter with the Infancy Gospel of James) as well as later writers.

${ }^{42}$ I have already noted in passing a number of themes attested in the classic Orthodox Icons of the Nativity; a fuller discussion can be found e.g. in Cartlidge and Elliott 2001.

${ }^{43}$ See e.g. Shoemaker 2010, esp. 155, 161-62 nn. 8-11.

${ }^{44}$ Hock 1995, 27, citing Quasten 1950, 1.122.
} 


\section{Conclusion: Scriptural Completion in the Infancy Gospel of James}

The infancy gospels may be said to take their cue from an implicit invitation in the eventually canonical texts themselves. Matthew and Luke are somewhat more forthcoming about Jesus' origins than John and Mark - in their provision of a family tree, narratives of his family and birth, and glimpses of his infancy. Matthew implicitly abandons the story when Jesus is still a toddler and even Luke provides only a single narrative of the boy Jesus at the age of twelve.

Yet a lively interest in these matters was already flourishing in the second century. The Infancy Gospel of James quite understandably takes up the question, with a particular emphasis on the role of Mary before and during the birth of Jesus. Although not intimately familiar with Palestinian Judaism, the author is perhaps more so than has sometimes been supposed, and is in any case attentive to several key concerns of the infancy narratives in both Matthew and Luke, including their Jewish setting. As we saw, the Infancy Gospel of James reflects widespread second-century traditions such as Jesus' birth in a cave and Mary's descent from David. And it supplies a range of other supplementary details, from the mundane (like the Virgin riding to Bethlehem on a donkey) to the supernatural (like the Creator's human birth causing creation and time themselves to pause).

Gospel-like writings of the second century generally do not presuppose a clearly delimited canon of four canonical gospels; and the Infancy Gospel is no exception, since at least its original composition must predate the New Testament's formal canonization. Nevertheless, it distinctly presupposes written or at least oral knowledge of the gospels of Matthew and Luke, without some sense of whose larger narrative the composition of this text would make little sense on its own.

Like other apocryphal Gospels, therefore, the Protevangelium is in an important sense supplementary and 'para-canonical' both in intent and in effect. It addresses implied readers already familiar with at least an outline of the ecclesial narrative of Jesus that went on to become canonical in fourfold form. The Protevangelium speaks alongside that larger narrative outline, whether its readers know this as a written gospel manuscript, a public liturgical gospel reading, or perhaps more diffusely in a second- or third-hand oral form.

Finally and more generally, what is true for the Infancy Gospel of James also characterizes most of the other apocryphal gospels, virtually all of which relate in some supplementary fashion, and however obliquely, to the core narrative of one or more of the canonical Four. They may attempt to fill in a perceived gap of some sort, whether this is chronological (as in the present case, building on implicit openings in Luke 1-2), thematic (as in the Jewish Christian gospels' sporadic glossing of Jesus' ministry and teaching with traditions relevant to their particular communities' concerns) or more comprehensive (as in the more expansive approach taken by some of the resurrection or 
discourse gospels). Even Mark's gospel, with its abrupt beginning and uncertain conclusion, might already seem to invite a certain scope for flexible prequels and sequels to its authoritative narrative from John's baptism to Easter Sunday.

In that sense the surviving non-canonical gospel texts can be understood as part of the proto-canonical tradition's history of effects and interpretation. Whether reflecting direct textual dependence or only quite indirect awareness of it, whether sympathetic or contrarian in their own approach, their Fortschreibung is part of the organic reception of that apostolic narrative tradition. (In some ways, of course, this is not fundamentally different from the relationship between the canonical Four themselves - or between them and the earlier oral teaching.)

Contact between Scriptural text and scriptural completion seems mediated by an encounter not so much with the written text of the discrete four gospels but equally, or perhaps more commonly, with a 'secondary oral', hybrid or harmonized form of tradition. Such texts remained epiphenomenal (and sometimes para-canonical) in relation to the gospel tradition that became canonized, but that relationship was both more informal and more intricate than has often been assumed in the past.

This sort of secondary gospel writing need not of course signify disapproval and intentional subversion of what goes before. Rather, it inevitably discloses a desire to re-appropriate and re-read the richness of the sacred narrative - perhaps to read better, or at least freshly or differently. This early Christian literary praxis follows richly developed precedent in Jewish biblical and post-biblical literature including the Dead Sea Scrolls and the so-called pseudepigrapha. ${ }^{45}$

Within the New Testament gospels, too, the effect of this kind of 'metatext' is at least as much to endow the evangelical predecessor with an implied authority as it is to improve and perhaps to replace. Early Christians clearly found in the 'texture' of the story of Jesus, in the warp and woof of its narrative openings and lacunae, an abundant invitation to receive and ponder the reality of the incarnation precisely in narrative form - in the process recognizing, exegeting and developing some of the most basic challenges of Christology. Much the same is also true in many or most of the other apocryphal 'rewritten gospel' narratives and 'agrapha' whose production and transmission continued during the second century, even at a time when the generation of apocalypses and other traditional literary forms seem to have declined.

${ }^{45}$ Cf. further Najman 2003, 1-40. 


\section{Works Cited}

Bauckham, Richard. 1994. "The Brothers and Sisters of Jesus: An Epiphanian Response to John P. Meier." Catholic Biblical Quarterly 56: 687-700.

Bauckham, Richard J. 1990. Jude and the Relatives of Jesus in the Early Church. Edinburgh: T\&T Clark.

Black, David Alan, ed. 2008. Perspectives on the Ending of Mark: 4 Views. Nashville: B \& H Academic.

Bock, Darrell L. 2006. The Missing Gospels: Unearthing the Truth Behind Alternative Christianities. Nashville: Nelson Books.

Bockmuehl, Markus. 2011. "The Son of David and His Mother." Journal of Theological Studies 62: 476-93.

Bockmuehl, Markus. 2017. Ancient Apocryphal Gospels. Interpretation: Resources for the Use of Scripture in the Church. Louisville: Westminster John Knox Press.

Bovon, Francois. 1991. "The Suspension of Time in Chapter 18 of Protevangelium Jacobi." In The Future of Early Christianity: Essays in Honor of Helmut Koester, 393-405. Ed. B. A. Pearson. Minneapolis: Fortress.

Brueggemann, Walter. 2003. An Introduction to the Old Testament: The Canon and Christian Imagination. First edition. Louisville: Westminster John Knox.

Byrskog, Samuel. 2000. Story as History - History as Story: The Gospel Tradition in the Context of Ancient Oral History. Wissenschaftliche Untersuchungen zum Neuen Testament 123. Tübingen: Mohr (Siebeck).

Cartlidge, David R. and J. K. Elliott. 2001. Art and the Christian Apocrypha. London/New York: Routledge.

Chapman, D. J. 1913. "On the Decretum Gelasianum De Libris Recipiendis et non Recipiendis." Revue Bénédictine 30: 187-208, 315-33.

Constas, Nicholas. 2003. Proclus of Constantinople and the Cult of the Virgin in Late Antiquity: Homilies 1-5,Texts and Translations. Supplements to Vigiliae Christianae 66. Leiden/Boston: Brill.

de Strycker, Émile. 1961. La forme la plus ancienne du Protévangile de Jacques. Subsidia Hagiographica 33. Bruxelles: Société des Bollandistes.

de Strycker, Émile. 1980. "Die griechischen Handschriften des Protevangeliums Iacobi." In Griechische Kodikologie und Textüberlieferung, 577-612. Ed. D. Harlfinger. Darmstadt: Wissenschaftliche Buchgesellschaft.

Ehrman, Bart D. and Zlatko Pleše, eds. 2011. The Apocryphal Gospels: Texts and Translations. New York: Oxford University Press.

Ehrman, Bart D. and Zlatko Pleše. 2014. The Other Gospels: Accounts of Jesus from Outside the New Testament. New York: Oxford University Press.

Frey, Jörg. 2011. "How Could Mark and John Do Without Infancy Stories?" In Infancy Gospels: Stories and Identities, 189-215. Ed. C. Clivaz et al. Wissenschaftliche Untersuchungen zum Neuen Testament 281. Tübingen: Mohr Siebeck.

Frey, Jörg. 2012. "B.VI.1 Das Freer-Logion." In Antike christliche Apokryphen in deutscher Übersetzung, 1.1-2 (Evangelien und Verwandtes):1059-61. Ed. C. Markschies and J. Schröter. Tübingen: Mohr Siebeck.

Gnilka, Joachim. 2007. Die Nazarener und der Koran: Eine Spurensuche. Freiburg: Herder.

Grossi, Vittorino. 2001. "Il "Decretum Gelasianum": Nota in margine all'autorità della Chiesa di Roma alla fine del sec. V." Augustinianum: 231-55.

Heckel, Theo K. 1999. Vom Evangelium des Markus zum viergestaltigen Evangelium. Wissenschaftliche Untersuchungen zum Neuen Testament 120. Tübingen: Mohr Siebeck. 
Hock, Ronald F. 1995. The Infancy Gospels of James and Thomas: With Introduction, Notes, and Original Text Featuring the New Scholars Version Translation. The Scholars Bible 2. Santa Rosa: Polebridge.

Ilan, Tal. 1997. Mine and Yours are Hers: Retrieving Women's History from Rabbinic Literature. Arbeiten zur Geschichte des antiken Judentums und des Urchristentums 41. Leiden/New York: Brill.

Jenkins, Philip. 2001. Hidden Gospels: How the Search for Jesus Lost Its Way. Oxford/New York: Oxford University Press.

Jensen, Robin M. 2015. "The Apocryphal Mary in Early Christian Art." In The Oxford Handbook of Early Christian Apocrypha, 289-305. Ed. A. Gregory and C. Tuckett. Oxford/New York: Oxford University Press.

Kelhoffer, James A. 2000. Miracle and Mission: The Authentication of Missionaries and their Message in the Longer Ending of Mark. Wissenschaftliche Untersuchungen zum Neuen Testament 2:112. Tübingen: Mohr Siebeck.

Kirk, Alan. 2007. "Tradition and Memory in the Gospel of Peter." In Das Evangelium nach Petrus: Text, Kontexte, Intertexte, 135-58. Ed. T. J. Kraus and T. Nicklas. Texte und Untersuchungen zur Geschichte der altchristlichen Literatur 158. Berlin/New York: Walter de Gruyter.

Lambers-Petry, Doris. 2003. "Verwandte Jesu als Referenzpersonen für das Judenchristentum." In The Image of the Judaeo-Christians in Ancient Jewish and Christian Literature, 32-52. Ed. P. J. Tomson and D. Lambers-Petry. Wissenschaftliche Untersuchungen zum Neuen Testament 158. Tübingen: Mohr Siebeck.

Levin, Yigal. 2006. "Jesus, 'Son of God' and 'Son of David': The 'Adoption' of Jesus into the Davidic Line." Journal for the Study of the New Testament 28, no. 4: 415-42.

Luther, Martin. 1883-2009. D. Martin Luthers Werke: Kritische Gesamtausgabe 120 vols. Weimar: H. Böhlau.

Luther, Martin. 1955-86. Luther's Works. Ed. J. Pelikan et al. 55 vols. American Edition. Saint Louis: Concordia.

Markschies, Christoph, Jens Schröter, and Andreas Heiser. 2012. Antike christliche Apokryphen in deutscher Übersetzung. Vol. 1.1-2: Evangelien und Verwandtes. Tübingen: Mohr Siebeck.

Najman, Hindy. 2003. Seconding Sinai: The Development of Mosaic Discourse in Second Temple Judaism. Supplements to the Journal for the Study of Judaism in the Persian, Hellenistic and Roman Period 77. Leiden/Boston: Brill.

Najman, Hindy. 2010. Past Renewals: Interpretative Authority, Renewed Revelation, and the Quest for Perfection in Jewish Antiquity. Supplements to the Journal for the Study of Judaism in the Persian, Hellenistic and Roman Period 53. Leiden etc.: Brill.

Najman, Hindy. 2012a. "Configuring the Text in Biblical Studies." In A Teacher for All Generations: Essays in Honor of James C. VanderKam, 3-22. Ed. E. F. Mason et al. Supplements to the Journal for the Study of Judaism 153. Leiden etc.: Brill.

Najman, Hindy. 2012b. "The Vitality of Scripture Within and Beyond the 'Canon'." Journal for the Study of Judaism in the Persian, Hellenistic and Roman Period 43: 497-518.

Nutzman, Megan. 2013. "Mary in the Protevangelium of James: A Jewish Woman in the Temple?" Greek, Roman, and Byzantine Studies 53: 551-78.

Ong, Walter J. 1982. Orality and Literacy: The Technologizing of the Word. London and New York: Routledge.

Pellegrini, Silvia. 2012. "B.V.5.1 Das Protevangelium des Jakobus." In Antike christliche Apokryphen in deutscher Übersetzung, 1.1-2 (Evangelien und Verwandtes):903-29. Ed. C. Markschies and J. Schröter. Tübingen: Mohr Siebeck.

Peppard, Michael. 2012. "Illuminating the Dura-Europos Baptistery: Comparanda for the Female Figures." Journal of Early Christian Studies 20: 543-74.

Quasten, Johannes. 1950. Patrology 4 vols. Westminster: Newman Press. 
Schwartz, E. 1930. "Zum Decretum Gelasianum." Zeitschrift für die neutestamentliche Wissenschaft 29: 161-68.

Shoemaker, Stephen J. 2010. "Apocrypha and Liturgy in the Fourth Century: The Case of the 'Six Books' Dormition Apocryphon." In Jewish and Christian Scriptures: The Function of "Canonical" and "Non-Canonical" Religious Texts, 153-63. Ed. J. H. Charlesworth and L. M. Macdonald. New York/London: Continuum.

Sly, Dorothy. 1990. Philo's Perception of Women. Brown Judaic Studies 209. Atlanta: Scholars Press.

Terian, Abraham. 2008. The Armenian Gospel of the Infancy: With Three Early Versions of the Protevangelium of James. Oxford: Oxford University Press.

Voicu, Sever J. 2011. "Ways to Survival for the Infancy Apocrypha." In Infancy Gospels: Stories and Identities, 401-17. Ed. C. Clivaz et al. Wissenschaftliche Untersuchungen zum Neuen Testament 281. Tübingen: Mohr Siebeck.

von Dobschütz, Ernst. 1912. Das Decretum Gelasianum de libris recipiendis et non recipiendis. Texte und Untersuchungen zur Geschichte der altchristlichen Literatur 38:4. Leipzig: Hinrichs.

Vuong, Lily C. 2013. Gender and Purity in the Protevangelium of James. Wissenschaftliche Untersuchungen zum Neuen Testament 2:358. Tübingen: Mohr Siebeck.

Warner, Martin Clive. 2003. Virginity Matters: Power and Ambiguity in the Attraction of the Virgin Mary. PhD dissertation, University of Durham.

Wüstenfeld, Ferdinand. 1861. Geschichte der Stadt Mekka: Nach den arabischen Chroniken bearbeitet. Leipzig: Brockhaus. 